\title{
Evaluation of barley distillers dried grains with soluble, and condensed distillers solubles in the diet of growing pigs
}

\author{
MATTI NÄSI \\ University of Helsinki, Department of Animal Husbandry, \\ SF-00710 HELSINKI 71, Finland
}

\begin{abstract}
Two digestibility and nitrogen balance trials were conducted to evaluate the feed value of barley-derived distillers dried grains with solubles (BDDGS) and semisolid distillers solubles from barley and wheat (BDS and WDS) in rations for growing pigs. The average crude protein, lysine, crude fibre and neutral detergent fibre contents of BDDGS, BDS and WDS were, respectively: $30.6,20.6,30.7 \% ; 1.7,1.7,2.6 \mathrm{~g} / 16 \mathrm{~g} \mathrm{~N} ; 16.1,2.0,3.1 \%$; $69.4,2.3,7.1 \%$. Available lysine was greatly reduced in all samples. The distillery by-products composed $33 \%$ of diet DM in the barley based rations. The control diet was a mixture of barley and skim milk powder. The organic matter and crude protein digestibilities of BDDGS, BDS and WDS were $40.5,80.4,85.0 \%$ and $52.4,46.9,77.5 \%$, respectively. Their FU values and DCP values were $0.50,0.94,0.94 / \mathrm{kg} \mathrm{DM}$ and $319,102,253 \mathrm{~g} / \mathrm{FU}$. on the WDS diet, nitrogen retention, as $\mathrm{g} / \mathrm{d}$, was similar to that on the control diet, but on the diets with barley distillery products it was reduced due to the lower amount of protein absorbed, especially the lower lysine intake. Barley distillers by-products proved to have low feed values for pigs in this study, but the value for WDS was quite reasonable. The new integrated starchethanol process can be expected to yield more suitable fractions for use in pig rations.
\end{abstract}

\section{Introduction}

Distillers by-products can be fractioned by screening or by centrifuging into solubles and grains, and these fractions can be dried together or separately to produce DDGS or DDG. The soluble fraction can be evaporated to a semisolid (PIEPER 1981). Distillers dried grains with solubles (DDGS) and whole stillage from wheat have been investigated in rations for growing pigs and it has been found that up to $5 \%$ and $10 \%$ of the pig feed can be replaced with DDGS and wetstillage, respectively (Alaviuhrola 1978, SuOMI 1980). NewMAn and Gras (1983) have reported that $5 \%$ barley dried distillers grains (BDDG) can be used to replace barley and soybean meal in diets for growing pigs. Higher levels tended to decrease the feed conversion efficiency, although the rate of gain was not impaired by up to $10 \%$ BDDG.

A new ethanol plant using barley as raw material will start operation in Finland in

Index words: Barley distillers grains with solubles, ethanol fermentation by-products, protein sources, pig feeds. 
1987. The process will be integrated ethanolstarch production, with an annual yield of 61700 tn DM grain fractions for feed purposes (LehmussaARI 1984). The increased supply of distillers products expected in the next few years has encouraged reevaluation of these products, especially barley residues, for which little information is available regarding utilization in pig diets.

The present study was designed to evaluate three distillery products as feed for growing pigs by detailed analyses of chemical composition, and measurements of nutrient digestibilities and utilization of protein.

\section{Materials and methods}

Two digestibility and nitrogen balance, trials were carried out, with four castrated Landrace pigs in each trial, during the growth period from 73 to $109 \mathrm{~kg}$. Barley distillers grains with solubles (BDDGS), and condensed wheat distillers solubles (WDS) composed $33 \%$ of the dry matter of the diet which was based on barley meal enriched with minerals and vitamins. The control ration was a barley, skim milk powder mixture $(85 \%+15 \%)$. In the second trial semisolid barley distillers solubles (BDS) composed $33 \%$ and $67 \%$ of the dry matter of the diet, which was based on barley. This trial had to be abandoned during the second period, due to the severe diarrhoea of the pigs receiving the larger amount of BDS. Each test period consisted of a 9-day adjustment and a 6-day collection period. The daily feed ration was $2.7 \mathrm{~kg}$, on average $85 \mathrm{~g} / \mathrm{kg}$ $\mathrm{W}^{0.75}$. The pigs were kept in metabolic cages, which allowed separate collection of faeces and urine. These were collected quantitatively twice daily and representative samples were frozen and stored until analysed. The pigs were weighed before and after the collection period.

Chemical analyses of the feeds and faeces were performed according to official procedures. Acid detergent fibre (ADF), neutral detergent fibre (NDF) and acid detergent lignin (ADL) were determined according to Coering and VAN Soest (1970). Amino acids were determined with a Technicon TSM autoanalyzer after hydrolysis of 6 hours in $6 \mathrm{~N}$ $\mathrm{HCl}$. The availability of lysine was measured according to CARPENTER (1960). The mineral composition was analysed with an atomabsorption spectrophotometer and phosphorus was determined by the method of TAYSSKY and SHORR (1953).

The digestibilities of the nutrients in the distillery products were calculated by the difference method, using measured values for barley and table values for skim milk powder. The feed values were calculated according to SAlo et al. (1982) and ANDERSEN and JUST (1979).

\section{Results and discussion}

BDDGS and WDS had a crude protein content around $30 \%$ of DM, but in BDS the value was $20 \%$ (Table 1). During yeast fermentation of grain, nearly all starch is removed, which concentrates the protein and other components. The crude fibre content of BDDGS was $16 \%$, which is in good accordance with the results of NEwMAN and Gras (1983). Barley contains 10-12\% hulls (Salo and Kotilainen 1970) and in DDG this percentage is increased, which is undesirable from the nutritional point of view since hulls consist of strawlike material. Barley also contains a fibre fraction primarily derived from endospermal cell walls, $\beta$-glucan, which is also poorly digested (CAmBell et al. 1984). In BDDGS the contents of total cell wall constituents (NDF), $69.4 \%$, and lignocellulosic material (ADF), $33.8 \%$, were high and exceeded the values $(65.2 \%$ and $28.2 \%)$ given by NEWMAN and Gras (1983). Condensed distillers solubles (BDS and WDS) had low values for ADF and NDF, which was due to the water solubility of these materials.

In BDDGS and BDS, especially the latter, most of the essential amino acids were lower 
Table 1. Chemical composition of distillers grain and solubles and barley meal, used in digestibility experiments with pigs.

\begin{tabular}{|c|c|c|c|c|}
\hline & BDDGS & BDS & WDS & Barley \\
\hline Dry matter & 94.3 & 71.2 & 34.4 & 87.9 \\
\hline Ash & 4.4 & 17.9 & 9.7 & 3.0 \\
\hline Crude protein & 30.6 & 20.6 & 30.7 & 11.2 \\
\hline True protein & 27.4 & 12.0 & 23.3 & 9.4 \\
\hline Ether extract & 6.8 & 1.5 & 7.5 & 2.5 \\
\hline Crude fibre & 16.1 & 2.0 & 3.1 & 5.6 \\
\hline Nitrogen-free extract & 42.0 & 57.9 & 49.0 & 77.7 \\
\hline Acid detergent fibre & 33.8 & 5.0 & 4.5 & 7.0 \\
\hline Neutral detergent fibre & 69.4 & 2.3 & 7.1 & 53.3 \\
\hline Acid detergent lignin & 13.5 & 3.4 & 1.9 & 1.1 \\
\hline Lignin & 7.9 & 0.9 & 0.4 & 2.0 \\
\hline Water soluble carbohydrates & 5.3 & 13.8 & 15.1 & \\
\hline \multicolumn{5}{|l|}{ Amino acids $\mathrm{g} / 16 \mathrm{~g} \mathrm{~N}$} \\
\hline Alanine & 4.3 & 3.7 & 3.4 & 3.5 \\
\hline Arginine & 3.3 & 2.1 & 3.5 & 4.6 \\
\hline Aspartic acid & 5.5 & 5.5 & 4.4 & 6.6 \\
\hline Glutamic acid & 20.8 & 13.6 & 17.5 & 19.0 \\
\hline Glycine & 3.9 & 4.7 & 4.2 & 3.8 \\
\hline Histidine & 2.4 & 2.7 & 2.8 & 2.3 \\
\hline Isoleucine & 4.0 & 2.5 & 2.8 & 2.6 \\
\hline Leucine & 7.8 & 4.2 & 5.7 & 6.1 \\
\hline Lysine & 1.7 & 1.7 & 2.6 & 3.4 \\
\hline Methionine & 0.8 & 0.4 & 0.8 & 1.1 \\
\hline Phenylalanine & 4.9 & 2.8 & 3.5 & 4.1 \\
\hline Serine & 4.0 & 3.9 & 4.3 & 3.9 \\
\hline Threonine & 3.6 & 3.7 & 3.1 & 3.9 \\
\hline Tyrosine & 2.7 & 2.2 & 2.7 & 2.1 \\
\hline Valine & 6.5 & 4.6 & 4.7 & 4.6 \\
\hline Available lysine & 0.35 & 0.5 & 1.5 & 3.1 \\
\hline \multicolumn{5}{|l|}{ Minerals } \\
\hline Phosphorus, g/kg DM & 5.09 & 16.16 & 17.05 & 3.98 \\
\hline Calcium, " & 0.65 & 1.35 & 0.61 & 0.53 \\
\hline Magnesium, " & 1.55 & 6.30 & 4.94 & 1.14 \\
\hline Sodium, " & 2.40 & 47.24 & 11.96 & 0.59 \\
\hline Potassium, " & 7.55 & 19.50 & 22.21 & 6.05 \\
\hline Iron, $\quad \mathrm{mg} / \mathrm{kg} \mathrm{DM}$ & 196 & 162 & 122 & 64 \\
\hline Copper, " " & 18 & 7 & 7 & 9 \\
\hline Zinc, & 67 & 116 & 33 & 61 \\
\hline Manganese, " & 38 & 98 & 69 & 21 \\
\hline
\end{tabular}

than in the original grain barley (Table 2). In both the products the lysine content was only $1.7 \mathrm{~g} / 16 \mathrm{~g} \mathrm{~N}$, whereas in barley it was twice as high. The available lysine was reduced to the minimal value of $0.35-0.5 \mathrm{~g}$. Methionine and threonine were also decreased. WDS had a sligtly better amino acid profile than the barley distillers products. Distillers products undergo heat and other processing treatments and these cause deamination and affect reactions with sugars, thus decreasing the biological value of the protein. AlaviuHKOLA (1978) and SALO (1978) found reduced lysine concentrations in wheat DDGS and decreased availability, too. SATterlee et al. (1976) and Newman and Gras (1983), how- 
Table 2. Digestibilities and nitrogen balance of diets containing distillers soluble or distillers grain with solubles compared with values for barley meal supplemented with skim milk powder,

\begin{tabular}{|c|c|c|c|c|c|c|c|c|}
\hline & \multicolumn{2}{|c|}{$\begin{array}{l}\text { BDS } 33 \% \\
\text { barley } 67 \% \\
\text { of diet }\end{array}$} & \multicolumn{2}{|c|}{$\begin{array}{c}\text { WDS } 33 \% \\
\text { barley } 67 \% \\
\text { of diet }\end{array}$} & \multicolumn{2}{|c|}{$\begin{array}{l}\text { BDDG } 33 \% \\
\text { barley } 67 \% \\
\text { of diet }\end{array}$} & \multicolumn{2}{|c|}{$\begin{array}{c}\text { Barley } 81.5 \% \\
\text { skim milk } \\
\text { powder } 16.4 \% \\
\text { of diet } \\
\end{array}$} \\
\hline & $\overline{\mathrm{x}}$ & s.d. & $\tilde{\mathrm{x}}$ & s.d. & $\tilde{x}$ & s.d. & $\overline{\mathrm{x}}$ & s.d. \\
\hline \multicolumn{9}{|l|}{ Digestibility } \\
\hline Dry matter & 81.0 & 2.0 & 83.5 & 0.4 & 69.4 & 0.8 & 85.4 & 0.7 \\
\hline Ash & 68.9 & 2.1 & 54.9 & 2.4 & 33.7 & 0.6 & 51.9 & 1.6 \\
\hline Organic matter & 82.1 & 1.9 & 85.6 & 0.4 & 71.2 & 0.8 & 87.2 & 0.7 \\
\hline Crude protein & 60.8 & 5.2 & 79.5 & 1.9 & 65.2 & 1.1 & 87.3 & 0.8 \\
\hline True protein & 56.4 & 5.6 & 82.8 & 1.4 & 68.6 & 1.3 & 89.4 & 1.0 \\
\hline Ether extract & 35.8 & 6.3 & 84.4 & 1.8 & 83.8 & 1.0 & 86.9 & 1.3 \\
\hline Crude fibre & 90.0 & 1.0 & 33.3 & 2.9 & 17.4 & 1.2 & 29.8 & 4.7 \\
\hline NFE & 88.7 & 4.2 & 90.8 & 0.2 & 79.4 & 1.0 & 90.0 & 0.6 \\
\hline \multicolumn{9}{|l|}{ Nitrogen balance } \\
\hline $\mathrm{N}$ intake, $\mathrm{g} / \mathrm{d}$ & 50.4 & 2.7 & 73.0 & 0.2 & 72.0 & 0.1 & 62.8 & 0.1 \\
\hline$N$ in faeces, $g / d$ & 19.8 & 3.4 & 15.0 & 1.4 & 25.0 & 0.7 & 8.0 & 0.5 \\
\hline $\mathrm{N}$ absorbed, $\mathrm{g} / \mathrm{d}$ & 30.5 & 1.5 & 58.1 & 1.4 & 46.9 & 0.8 & 54.8 & 0.5 \\
\hline $\mathrm{N}$ in urine, $\mathrm{g} / \mathrm{d}$ & 18.9 & 1.0 & 36.3 & 2.3 & 32.2 & 0.8 & 35.6 & 0.8 \\
\hline$N$ retained, $g / d$ & 11.6 & 2.3 & 21.7 & 2.0 & 14.7 & 0.8 & 19.2 & 1.2 \\
\hline$\%$ of intake & 23.2 & 5.6 & 29.8 & 2.7 & 20.5 & 1.0 & 30.5 & 1.9 \\
\hline$\%$ of absorption & 37.8 & 5.8 & 37.4 & 3.6 & 31.4 & 1.4 & 34.9 & 1.9 \\
\hline Biological value & 51.2 & 4.5 & 45.9 & 3.4 & 42.6 & 1.2 & 44.7 & 1.8 \\
\hline
\end{tabular}

ever, found fairly similar amino acid profiles in wheat, corn and barley DDG compared with the original grains.

The sodium, potassium and phosphorus contents were higher in condensed distillery solubles than in barley (Table 1). Sodium is added in fermentation to adjust the $\mathrm{pH}$ (LehmussaARi 1983). The high sodium content in BDS was probably the reason for diarrhoea in the pigs receiving the larger amount of solubles in the second trial.

On the diet containing WDS, nitrogen retention was almost the same as on the control diet but on the diets containing barley distillers products, nitrogen retention was decreased. The differences are mostly due to the differences in DCP intakes, which were $191,363,293$ and $343 \mathrm{~g} / \mathrm{d}$ on the BDS, WDS, BDDG and control diets, respectively. The lysine intakes were 12.2, 14.2, 12.0 and $19.0 \mathrm{~g} / \mathrm{d}$, respectively. The availability of lysine was also much reduced in both barley distillery products. However, the results of Newman and Gras (1983) indicated that apparent nitrogen retention was not affected when BDDG replaced soybean, composing up to $20 \%$ of the diet. Thong et al. (1978) measured nitrogen retention with gilts and found no differences between DDGS and soybean used as protein supplements.

The digestibility coefficients indicated that WDS was similar to barley, though the crude protein was $5 \%$-units less digestible. BDS had slightly lower values for organic matter and NFE digestibility, but crude protein digestibility was only half that of barley. Barley BDGS was digested poorly by the pigs (Table 3). The values were lower than those measured with ruminants (Näsı 1984). The organic matter digestibilities of distillers byproducts are reported as $54-63 \%$ for wheat (SAlo 1978), $80 \%$ for maize and $74 \%$ for potato (Roth and KirChgessner 1975); the crude protein digestibilities were $63-67 \%$, 
Table 3. Digestibility coefficients of distillers grain and solubles and calculated feed values.

\begin{tabular}{|c|c|c|c|c|}
\hline & $\begin{array}{c}\text { Barley } \\
\text { distillers } \\
\text { solubles }\end{array}$ & $\begin{array}{l}\text { Wheat } \\
\text { distillers } \\
\text { solubles }\end{array}$ & $\begin{array}{l}\text { Barley dis- } \\
\text { tillers grain } \\
\text { with solubles }\end{array}$ & Barley \\
\hline \multicolumn{5}{|l|}{ Digestibilities } \\
\hline Dry matter & 80.4 & 83.1 & 38.9 & 83.7 \\
\hline Organic matter & 80.4 & 85.0 & 40.5 & 85.8 \\
\hline Crude protein & 46.9 & 77.5 & 52.4 & 82.2 \\
\hline True protein & 31.8 & 80.8 & 56.8 & 85.2 \\
\hline Ether extract & 18.4 & 82.8 & 81.5 & 86.9 \\
\hline Crude fibre & 204.1 & 44.2 & 8.2 & 30.3 \\
\hline NFE & 90.0 & 92.3 & 37.2 & 90.4 \\
\hline \multicolumn{5}{|l|}{ Feed values } \\
\hline FU/kg DM & 0.94 & 0.94 & 0.50 & 1.16 \\
\hline $\mathrm{kg} / \mathrm{FU}$ & 1.49 & 3.09 & 2.11 & 0.98 \\
\hline $\mathrm{DCP}$ in $\mathrm{DM}, \%$ & 9.7 & 23.8 & 16.1 & 9.2 \\
\hline $\mathrm{g} \mathrm{DCP} / \mathrm{FU}$ & 102 & 253 & 319 & 78 \\
\hline \multicolumn{5}{|l|}{ Just system } \\
\hline $\mathrm{ME} \mathrm{MJ} / \mathrm{kg} \mathrm{DM}$ & 14.66 & 15.44 & 8.45 & 15.14 \\
\hline $\mathrm{NE} \mathrm{MJ/kg} \mathrm{DM}$ & 9.12 & 9.70 & 4.46 & 9.48 \\
\hline NE FU/kg DM & 1.18 & 1.26 & 0.58 & 1.23 \\
\hline \multicolumn{5}{|l|}{ Axelsson } \\
\hline $\mathrm{ME} \mathrm{MJ/kg} \mathrm{DM}$ & 14.40 & 14.70 & 7.90 & 14.83 \\
\hline
\end{tabular}

$53 \%$ and $55 \%$, respectively. NEWMAN and Gras (1983) did not find any differences in nitrogen digestibility between diets when up to $20 \%$ of the soybean was replaced by BDDG.

When feed values were calculated from the chemical composition and digestibility values, both condensed solubles were found to have a FU value of $0.94 / \mathrm{kg} \mathrm{DM}$, but the value for BDDGS was low, $0.50 / \mathrm{kg}$ DM. The DCP value for BDS was low, about the same as in grain, but WDS and BDDGS had higher values, $253-319 \mathrm{~g} / \mathrm{FU}$.

When barley distillery by-products are used in pig diets, the hull content has to be decreased to obtain an adequate energy value, and thermal processing treatments should be estricted as far as possible, to avoid impairing protein availability. The new integrated starch-ethanol process yields fractions which are more suitable for use in pig feeding.

\section{References}

Alaviuhkola, T. 1978. Rankkijauho lihasikojen rehuna. Koetoiminta ja Käytäntő 31. 10. 1978.

Andersen, P.E. \& Just, A. 1979. Tabeller over fodermidlers sammensaetning m.m. kvaeg, svin. Det kgl. danske Landhusholdningsselskap. Kobenhavm. 56 p.

Campbell, G.L., Classen, H.L. \& Salmon, R.E. 1984. Enzyme supplementation of barley diets for broilers. Feedstuffs 56 (19): 26-27.
CARPENTER, K.J. 1960. The Estimation of the Available Lysine in Animal - Protein Foods. Biochem. J. 77: $604-610$.

Coering, H.K. \& Van Soest, P.J. 1970. Forage fiber analyses: apparatus, reagents, procedures and some applications. U.S. Dep. Agric. Handb. No 379: 8-9. LeHMUSSAARI, A. 1983. personal communication.

-, 1984. Integroitu tuotanto. Etanoli - tärkkelys - 
tărkkelyssokeri. Esitelmä. Oy ALKO Ab. Process Engen. Division Rajamäki. 5 p.

Newman, C.W. \& Gras, P.W. 1983. Utilization of barley distillers dried grains in swine growing diets. Proc. West. Sect. Am. Soc. Anim. Sci. 34: 138-141.

NÄsı, M. 1984. Distillers dried by-products from barley as protein source for ruminants. J. Agric. Sci. Finl. 56: $213-219$.

PIEPER, H.J. 1981. Gărungstechnologische Alkoholproduktion. Handels Futtermittel 2 A: 91-106.

Roth, F.X. \& Kirchgessner, M. 1975. Zum Futterwert getrockneter Kartoffel- und Maisschlempe beim Schwein. Das Wirtschaftseigene Futter 21: 225-231.

SAlo, M.L. 1978. Vehnärankkijauhon rehuarvo lihasikojen ruokinnassa. J. Scient. Agric. Soc. Finl. 50: 291-295.

—, \& Kotilainen, K. 1970. On the carbohydrate composition and nutritive value of some cereals. J. Scient. Agric. Soc. Finl. 42: 21-29.
-, TUORI, M. \& Kinskinen, T. 1982. Rehutaulukot ja ruokintanormit. $70 \mathrm{p}$.

Satterlee, L.D., Vavak, D.M., Abdul-Kadir, R. \& Kendrik, J.G. 1976. The chemical, functional and nutritional characterization of protein concentrates from distillers grains. Cereal Chemistry 53: 739-749.

Suomı, K. 1980. Tuore rankki lihasikojen rehuna. Koetoiminta ja Käytäntö 1. 7. 1980.

TAYSSKY, H.H. \& SHORR, E. 1953. A microcolorimetric method for the determination of inorganic phosphorus. J. Biol. Chem. 202: 675-685.

Thong, L.A., Jensen, A.H., Harmon, B.G. \& CorneLuUS, S.G. 1978. Distillers dried grains with solubles as a supplemental protein source in diets for gestating swine. J. Anim. Sci. 46: 674-677.

Ms received August 17, 1984

\title{
SELOSTUS
}

\section{Ohrarankkirehun ja rankkiuutteen arvo lihasikojen rehuna}

\author{
Matti Näsi \\ Helsingin yliopisto, Kotieläintieteen laitos, \\ 00710 Helsinki
}

Sulavuus- ja typpitasekokeissa tutkittiin rankkituotteiden rehuarvoa ja valkuaisen hyväksikäyttöä kasvavilla lihasioilla. Ohrarankkirehussa oli raakavalkuaista $30.6 \%$, lysiiniä $1.7 \mathrm{~g} / 16 \mathrm{~g} \mathrm{~N}$ ja raakakuitua $16.1 \%$ ka:ssa ja vastaavasti ohra- ja vehnärankkiuutteissa 20.6, $30.7 \% ; 1.7,2.6$ g sekä 2.0 ja $3.1 \%$. Käyttőkelpoisen lysiinin maaărä oli kaikissa rankkituotteissa hyvin alhainen. Eri rankkituotteilla korvattiin $33 \%$ dieetin kuivaaineesta sulavuusmäärityksissä. Ohrarankkirehun sekä ohra- ja vehnärankkiuutieen orgaanisen aineen ja raakavalkuaisen sulavuuksiksi saatiin $40.5,80.4$ ja $85.0 \%$ sekả $52.4,46.9$ ja $77.5 \%$, vastaavasti. Laskennallisiksi rehuyksikköarvoiksi ja sulavan raakavalkuaisen mää- riksi saatiin $0.50,0.94$ ja $0.94 \mathrm{ry} / \mathrm{kg}$ ka sekä 319,102 ja $253 \mathrm{~g} \mathrm{srv} / \mathrm{ry}$. Typen pidättyminen oli vehnärankkiuutedieetillă samanlaista kuin vertailudieetillä, mutta ohrarankkituotteita sisältäneillă dieeteillä huomattavasti văhäisempää, koska siat saivat näillă dieeteillă sulavaa valkuaista ja erityisesti lysiiniă edellisiă văhemmăn.

Ohrarankkituotteiden käyttökelpoisuus sikojen ruokinnassa on heikko johtuen valkuaisen alhaisesta sulavuudesta ja puutteellisesta aminohappokoostumuksesta. Lisäksi korkean kuitupitoisuuden takia ohrarankkirehun sulavuus jäi văhăiseksi. Käyttökelpoisia rehufraktioita on mahdollista saada integroidusta etanolitärkkelystuotannosta myös sikojen ruokintaan. 